\title{
Rural women's access to and control over land in East Gojjam during the Derg and EPRDF
}

\author{
Birtukan Atinkut Asmare
}

\begin{abstract}
Background: The main purpose of this paper was to identify the status of rural women to access and control over land in East Gojjam since 1974. Despite measures taken to ensure gender equality in land ownership since 1974, women in Ethiopia in general and in East Gojjam in particular experienced more challenges related with access to and control over land.
\end{abstract}

Results: In Gojjam, the first redistribution of land during the Derg regime took place 3 years later after the 1975 land reform. Although the reform granted female headed households to equal access of land based on their household sizes, they were allocated unproductive, swampy and marginal lands attributed to patriarchal social norms, customary practices and poor legal services. However, since 1991 women's status to land ownership was relatively changed. All women, despite differences in marital status, were entitled to independent land ownership with land certificate to increase security during divorce or land related disputes. In order to realize the intended objectives, both primary and secondary sources of data were collected. Primary sources of information were collected through interviews and focus group discussions with elderly people, women, husbands, relatives of women, government authorities at kebele and woreda level.

Conclusions: The introduction of land certificate has relatively reduced boundary disputes and increased the confidence and the status of women in the society. However, there are significant challenges in terms of the degree of access and control women have over land. Thus, attention should be given in addressing constraints related with women's land right.

Keywords: Women, Access, Control over, Challenges

\section{Background}

In rural Ethiopia land is not only material and productive resource that enable livelihood of the rural community, but it is also an important symbolic resource that heavily influences status and identity (Teshome 2015). Particularly, for rural women, land is an important resource especially when the household broke up due to migration, war, abandonment, divorce, polygamous relationships, illness or death (Agarwal 1994) and it is the most fundamental resource to their living conditions, economic empowerment and, to some extent, their struggle

*Correspondence: brtknst197@yahoo.com

Department of History and Heritage Management, Faculty of Social Sciences, Bahir Dar University, Bahir Dar, Ethiopia for equity and equality (Teshome 2015). In rural Ethiopia women constitute half of the country's population and play critical role in agricultural production, where they make up the majority of the agricultural workforce by which over $50-80 \%$ of the labor force required in crops and livestock production as well as environmental rehabilitation is performed by women (Alemayehu 2001; Ojulu 2015; Gashaw 2015). In the Amhara region, where the study area forms apart, the time and labor input of women in crop production is found to be 50 \% (Wudenesh 2003).

However, the existing literature shows that despite women's significant contribution to the agricultural sector, as women in others parts of the developing world,

\section{Springer}

(c) 2016 Asmare. This article is distributed under the terms of the Creative Commons Attribution 4.0 International License (http:// creativecommons.org/licenses/by/4.0/), which permits unrestricted use, distribution, and reproduction in any medium, provided you give appropriate credit to the original author(s) and the source, provide a link to the Creative Commons license, and indicate if changes were made. 
women in Ethiopia historically had no or limited access to and control over important agricultural resources such as land, livestock, farm implements, capital, knowledge and information (Lemlem et al. 2011; Sachs 1996; Zenebe 2005; Sintayehu 2003; Fong and Bhushan 1996). Teshome (2015) also noted that due to economic, legal, social and cultural factors women's right to access and control over land are weaker compared to their male counterpart.

Even women with access to land do not have actual control over land. The studies of (Agarwal 1997; Davison 1988; Deere and León 2001; Teklu 2005; Verma 2007) noted that even though constitution and legislations that favors women's land use right existed in Ethiopia, gender equality has not been achieved and women do not enjoy equal land right with men which is deeply rooted in social, political and power relations. (Hadera 2002; Teshome 2015; Tenaw et al. 2009) argued that though, women have policy support over farmland possession in Ethiopia, the socio-cultural norms and customary practices did not allow women to decide whether and how a resource should be used, how it is to be allocated and share the benefits. This in turn made women one of the most vulnerable groups of the society, socially inferior and economically dependent on men.

The tenure system in Ethiopia has undergone numerous reforms over centuries. Prior to 1974, tenure systems failed to provide women with secure rights to land. Women could only inherit rist land from their parents or deceased husbands as they are only granted usufructuary rights (Hadera 2002; Ojulu 2015; Zenebe 2005). With the 1974 state change, the feudal tenure arrangement was replaced by state owned type of land right of the military government. Although the Derg regime's land reform was relatively progressive, in practice it did not benefit all women (Teshome 2015; Hadera 2002). The 1995 constitution of Ethiopia has put in place gender sensitive policies and proclamations that granted women to acquire, administer, control, use and transfer and inherit land (FDRE 1995; Hadera 2002; Hussein 2014), despite some of the limitations.

However, there is limited study on women's access to and control over land during the two consecutive regimes: the Derg (r. 1974-1991) and EPRDF (Ethiopian Peoples Republic Democratic Front (r. 1991 onwards) in East Gojjam. Thus, what prompts this discussion is the fact that the history of women access and control over land remains relatively unexplored, and within this context, how women in Ethiopia in the framework of the changing political regimes accessed land and benefiting from land, has not been adequately researched. Thus, this paper attempts to fill this gap, so that it can contribute to the hardly existing literature and provides an insight for policy makers in developing the appropriate land policy which ensures gender equality in land ownership. In order to achieve the expected outcome, two important research questions were formulated; (i) did women have had equal access to land with men and did they equally controlled land during the Derg and EPRDF in East Gojjam and (ii) what were the challenges women faced in their struggle to access and control over land. The research is targeted to use the experiences from East Gojjam zone to highlight the challenges that rural women in that area are facing in relation with land in order to discuss challenges that are likely to occur also in other parts of Ethiopia. Accordingly, the forthcoming section highlights a brief overview of change and continuity in land access and control over by Ethiopian women in general, and more specifically in East Gojjam across the two consecutive regimes.

\section{Methods of the study}

\section{Description of the study area}

This study is carried out in East Gojjam, situated in the northwest part of Ethiopia, in the Amhara regional state. It is bordered by South Gonder in the north, South Wollo in the east, North Shewa in the southeast, East Wollega in the southwest and West Gojjam in the west. The Abbay River is the border of East Gojjam from the northeast through to the east, up to southwest. East Gojjam Zone has a population of 2,153,937 (of these $90 \%$ were rural and $10 \%$ urban) (CSA, 2007) (Fig. 1).

To undertake this research, qualitative research method was employed. Data were collected from both primary and secondary sources. Purposive sampling was used to select key informants and focus group participants on the basis of their role on land related issues. Thus,

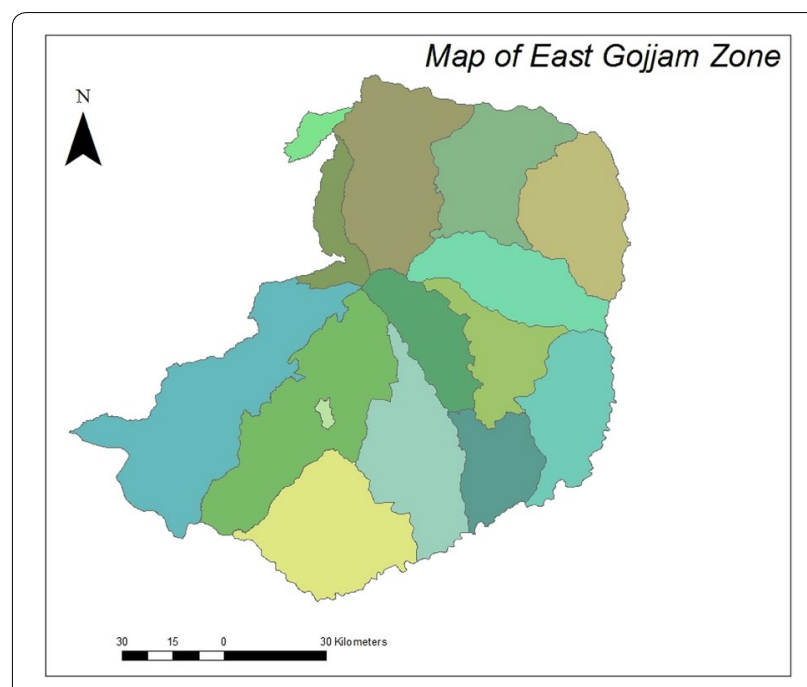

Fig. 1 Map of the study area 
primary sources were gathered through in-depth interview and focus group discussion (FGD) with local communities such as the elderly, married women, divorced/ widowed/single women, husbands, relatives of women, women of different ages and government authorities at kebele (lowest administrative unit) and woreda (district) level to get a range of perspectives in land administration process and their knowledge and experience over land issue. Open ended questions were used because it allows the researcher to look into things beyond systematically prepared questions and it is helpful for the researcher to ask the respondents in different ways on the basis of their ability. Twenty five key informants were participated in the interview.

For this study, the role of focus group discussion was not negligible. It had significant role in digging out most agreed upon information on women's experience on rights and control over resources mainly land, household resources and decision-making power at household level, and the challenges that women experienced. The participants were an important source of information for the group discussion as far as they have had similar lifestyles. Taking into account the homogeneity of the group in terms of age, status and sex of the focus group discussion participants, the researcher carried out five focus group discussions. Each focus group discussion comprised of 6-10 participants. The participants of the FGD were women (both divorced/widowed/married), husbands, elderly people and local administration authorities. Moreover, in order to substantiate the data, secondary sources were refereed through reviewing relevant literatures, historical documents, government land policy documents/proclamations on land tenure system, on gender roles and access to and control over livelihood resources.

As it is clearly noted in the study of Creswell (2005), analysis of qualitative data began during data collection. Thus, it was during data collection by which documenting key informant interviews and focus group discussions was started. Then after, the audio-recorded data was translated from Amharic to English, in spite of the fact that few words were kept as it is, in order not to lose their meaning. Finally, the data collected from different categories of sources were analyzed using descriptions, interpretations and comparisons. Qualitative information from the individual interviews was also written as quotations to comprehensively understand differences in gender based relations over rural household livelihoods of the study area.

\section{Women access to and control over land The Derg period (r. 1974-1991)}

Women play significant role in agricultural productivity, carrying out an estimated $40-60 \%$ of all agricultural labour (World Bank 2008 as cited in Lemlem et al. 2011), though, they suffered from unequal access to land. Prior to 1974 women could inherit rist land from their parents or deceased husbands. In this period women's land right were highly subjected to birth or marital families (Hadera 2002; Mintewab and Holden 2010; Kebede 2008).

After the overthrow of the monarchy in 1974, however, the Derg regime immediately introduced a radical nationwide programme of nationalization of all rural land. This was effected through the 1975 proclamation which provided for public ownership of rural land (Hadera 2002; Mintewab and Holden 2010). The 1975 reform granted all peasants and tenants to maintain and held the land which they previously farmed and freed them from any exploitation by the landlords (Daniel 2012). All extra lands were confiscated and distributed to landless peasants, on the basis of the popular slogan of Ethiopian students of the 1960s, "land to the tiller." In principle, this reform was a means to end the exploitation of peasants by absentee landlords (which was mostly practiced in the southern part of Ethiopia). The reform also seemed gender-sensitive which recognized equal rights of both men and women to acquire rural land under Proclamation No. 31/1975. The land policy of the government stated: "without differentiation of the sexes, any person who is willing to personally cultivate land shall be allotted rural land sufficient for his maintenance and that of his family" (Hadera 2002).

The administration and distribution of land was given to the peasant associations (PA) created in every village of 800 hectares of land (Daniel 2012). The information collected from informants and FGD participants reveal that in such distribution, female headed households got due attention from the government. A case in point, when all extra lands were confiscated from the land owners and distributed to the landless, female-headed households did not lose their rist land that was owned prior to 1975. Consequently, based on the proclamation, land was distributed based on household sizes, without differentiation of sexes. In Gojjam, all female headed households acquired equal access of land with male-headed households based on their household size, particularly in the distribution that took place between 1978-9. This was an indication of the government's attempt to ensure gender equality in land related issues.

However, distortions in the process of implementation and lack of the necessary will to carry out genuine land reform increased gender-based disparity that negatively affected women (Hadera 2002). This was because land was distributed for household heads, not to each member of the household; as a result, those married women were totally excluded from receiving land independently, since the land was registered in husband's name. Secondly, the 
phrase "to personally cultivate" had negative implication for women since it had been directly translated to mean using oxen for plowing, which is culturally forbidden for women. Such interpretation became an obstacle for women to access and control over land.

In addition to this, it was found that the land allocated to female headed households were unfertile, swampy, marginal, required labor for preparation and far away from homesteads (Meheret 1994). The information collected from the informants also revealed that this problem was more aggravated by the appropriation of women's land caused as a result of frequent and periodic redistribution of land since the 1975 land reform. (Stefan and Daniel 2007) also stressed that periodic land redistributions were made to accommodate the newly formed households, which in turn led to widespread land tenure insecurity and loss of holdings.

Moreover, the 1975 land policies and proclamations were poorly implemented especially to protect women's right of land during divorce and the death of a husband. As a result, land related disputes were mainly dictated traditionally. A case in point, if it is a husband that wants to get divorce, women can get equal access to a household land. But it would have been impossible to use the land if a divorced woman left her residence and went to other kebles or areas. If she left the kebele or remarried outside the kebele, the land could be appropriated by the PA officials as yemote keda land and the woman would be forced to leave the area with nothing. On the other hand, if it is a woman that wanted to get divorce and if a woman had no relatives and financial capacity, she would be forced to leave the homestead without having a share of land from the matrimonial property. Women were in difficulty making claims to their family's land without male relatives.

As a consequence, many women migrated to the nearby towns, where they practice prostitution (infected by HIVAIDS) and selling local drinks (tella or areke) to supplement their income. Many others migrated to the Arab World, where they can obtain paid employment. (Zenebwork 2000; Yigremew 1997) also noted that women failed to get justice in times of divorce and hence they had either go back to their relatives or run away to other places to look for means of survival.

\section{A divorced woman experience in machacal woreda (East Gojjam)}

Upon the death of my father, I left to the nearby areas to find paid job. Sooner, I got married with a man and I gave birth to five children. Consequently, my husband becomes aggressive and bits me all the time. I requested my mother to get divorce with my husband. However, my husband refused to give me a piece of land to me and my children, since I was the one who wanted to get divorce. Me and my children go back to my mother's house, where one can find little food. I frequently asked my husband with community elders to give me my share. But he negatively responded that entitlement is given to me, not for you, just live as you did previously. The only option I had was working as a maid in the town, by abandoning my children with my old mother.

The information collected from informants reveals that during the death of a husband women did not have the right to inherit the land, rather it would be given to a grown-up male child. If the husband died without having children, the committee would appropriate half of the holding, otherwise the brother-in-law inherits the property. Widowed women with children are relatively better secured. Yared (1995) noted that PA officials take a major part of the land when the male spouse dies while they take a small plot or none upon the wife's death. This is done under the pretext that the man can re-marry and sustain the family while the woman's chances of re-marrying is minimal and the possibility of leaving her area of residence is very high. Yared further observes that social status and economic resources are important in influencing the pattern of land distribution, which disadvantages female headed households given the lower social status of women and their minimal economic resources. Dessalegn (1994) underscores the fact that although women hold land on behalf of their male children, they may be deprived of all or part of it when the boys grow up and claim it."

\section{Experience of widowed woman in Debre Elias woreda (East Gojjam)}

My marriage was not able to be blessed with children, though we had every resources. My husband died after four years of marriage. Forty days later after his death, the PA officials confiscated my land, without my awareness. When I realized that my land was appropriated, I requested the community leaders. They said that you do not have children and you are getting older and no possibility to remarry another man, the probability to leave this place is high as long as you have nothing to stay. Thus, since the law favors men over women, I was not able to go to the court.

Land reform did not change women's subordinate status, which was based on deep-rooted traditional values and beliefs. Despite women's role, their position in decision making is documented to be minimal. Men tend 
to control the income from crops and livestock commodities where women dominate or share the workload such as field crops, vegetables and tree planting. Only in female-headed households do women control the decisions regarding use of agricultural technologies; yet this still tends to be in consultation with their male relatives (Anteneh 2008). Such lack of decision making power over land prohibited women to determine the types of crops to be planted, the type of decisions should be passed on the improvement of land, to either sharecrop or rent the farm land, whether to use fertilizers and other farm technologies, and whether and when to hire labour. The information collected from the informants and FGD reveals that only less valued assets such as hens, egg, animal products; like milk and butter were allowed for women. Men usually avoided consulting their wives especially on matters which requires serious decision making like leasing/selling land.

Dessalegn (1994) and Zenebwork and Yared (2000) concluded that the 1975 land reform "neither totally discriminated against women's right to land nor did it improve their situation substantially." It failed to ensure equal land rights of women. Zenebwork and Yared (2000) noted that "among other things, the 1975 land reform was criticized for its failure to challenge the cultural taboo against women ploughing and sowing because this reaffirmed the beliefs, practices and contracts which governed land relations between men and women."

\section{EPRDF (r. 1991 onwards)}

After the overthrow of the Derg regime from power in 1991, the 1995 Federal Democratic Republic of Ethiopia (FDRE) Constitution declared land to be the property of the State and the People of Ethiopia. Article 40 sub-article (3) of the constitution stated that "The right to ownership of rural and urban land, as well as of all natural resources, is exclusively vested in the state and the peoples of Ethiopia. Land is a common property of the Nations, Nationalities and Peoples of Ethiopia and shall not be subject to sale or to other means of exchange" (Hadera 2002).

Taking the historical legacy of women's discrimination, the government has exclusively initiated many strategic activities toward gender equality and promotion of women's right in land ownership. The FDRE Constitution under Article 4(4) of the Proclamation underscores the fact that: "The land administration law of the regions shall confirm the equal rights of women in respect of the use, administration and control of land as well as in respect of transferring and bequeathing holding rights" (Hadera 2002; Anteneh 2008). Based on this, each regions of Ethiopia started to put the proclamation into practice. In the Amhara region, for instance, land was distributed a year later after the the formulation of the constitution for any individual woman over 18 years old or man over 24 years old by the local kebele administration (Anteneh 2008; Crewett et al. 2008; Gebreselassie 2006; Askale 2005; Zenebwork and Yared 2000). In this distribution, former derg officials (locally called bureaucrats) lost some plots of land as a result of the accusation made against them that they took fertile and wet land for themselves during the 1975 land distribution. Others; landless farmers, recently married couples, female-headed households and unmarried women with children and other land deficient households received at least four timads (an equivalent of one hectare) of land depending on the availability of land in the rural kebele (Yigremew 1997, cited in Zenebwork and Yared 2000).

In East Gojam, the average land size distributed per person varied from 1 hectare to 4 hectares (Askale 2005). Landless females were allocated land ranged from 0.5-4 timads of land based on household sizes. $57.9 \%$ of female-headed households allocated less than two timads, $33.55 \%$ allocated two timads and only $8.55 \%$ obtained more than two timads. Thus, the 1996 land redistribution has relatively changed the status of women from being secondary right-holders to primary holders (Askale 2005).

Tenure security is another policy objective and concern of the government. In order to increase security over land and to deal with the problematic situation women experienced, land certificate program was introduced in 2003. The land certificate holds both the name of the husband and wife and includes list of all measured plots and names of family members, including monogamous married couples and their legitimate children. Both the husband and wife should acknowledge the receipt of the certificate with their signatures. The land certificate recognized the right of women in times of transfer of land through inheritance, rental and donation in that this can be only legal when the wife supports it. It also grants, men and women borrow bank loans by using the certified land. It also ratified the right of women to equal share of the land they were holding jointly, in times of divorce. This provision has been put into practice by registering household land as a joint resource and providing the book that ensures joint ownership (Askale 2005; Anteneh 2008). Thus, a large majority of women have secured land titles either jointly with their husbands or independently.

The current practice of land registration and certification provides tenure security. It has been claimed that it reduces land related disputes as land is registered and certified (Assefa 2010; Deininger et al. 2007). Single women, who were disrupted by men due to the absence of certificate, are now relatively free of boundary conflicts since the plot is clearly shown on the land certificate. In 
the Amhara region including East Gojjam the number of court cases on land has been reduced substantially from 40 to 2 per week, though there are few boundary disputes caused when the family of the deceased husband wants to maintain and control all of the land, leaving the widowed with nothing, selling inherited plots, when children in polygamous marriages raises the issue of inheritance during the death of a husband. However, the land policies and laws of the current regime better protects women rights over land.

Besides, the certificate reduces the divorce rate at household level. Prior to the registration of land divorce happens every time. Currently, certification of land increased certain level of tolerance among men in order not to lose land following divorce, although there were few men who got divorced before the land registration took place, to gain full control of their land.

However, polices and laws that are formulated to bring gender equality could not change the traditions and customary laws that has been exercised within the society for years. Customary practices could not change the status of men as the owner and head of the household, who is supposed to exercise power over the use and management of household's resources mainly land, most valuable resources of the society. Such type of perception of men has always been a source of conflict between a wife and a husband. Thus, there is still a gap between owning land titles and the enjoyment of the benefits accruing from them, since some women are still involved in different kinds of land-related conflicts and face challenges related to the control and legitimacy of their land rights.

Besides, laws and policies do not offer protection to women whose marriages are not registered and their right to land is dictated traditionally (Askale 2005). Zenebwork and Yared (2000) found that women in polygamous marriages are largely disadvantaged since husbands usually registered one wife usually the housewife, denying the right of other wives to access land. Contrary to this, a study conducted by Hussein (2014) in Wolayita, shows that women in polygamous marriage are not disadvantaged social groups of the society, particularly when polygamous marriage is arranged based on the consent of a housewife in times of infertility and ageing of a housewife. Such type of arrangement usually allows wives to share the fruits of the land and the plots.

Dessalegn (2009) noted that land registration and certification had not brought about the feeling of tenure security. Since the land laws do not avoid completely the possibilities of future land distribution and since government still possesses the power of taking land by way of expropriation, farmers could not feel secure on their holdings.
Equal access of land and certification did not increase women's right to equally use of land attributed to various reasons. Married women could have plow their land with their husbands, while female headed households are largely influenced by access to labor, oxen, social and economic assets and family support. The ox-plough farming system and cultural taboos on women ploughing and sowing had affected women's right on land particularly that of female headed households (Rahmato 1994; Askale 2005). As a consequence, female headed households who own farm land have to either hire male labour for cash or exchange their oxen for labor to produce agricultural products.

According to the study undertaken by (Dessalegn 1994; Ojulu 2015), "female headed households tend to be poorer and in need of assistance particularly for labor on the farms and such work as sowing and ploughing, is traditionally considered to be taboo for women to do. Their dependence on male labor and frequent renting of traction power imposes problems on women and, as a result, their land is often not ploughed, seeded or harvested in time. As a result, female headed households have more acute lack of agricultural resources and are sometimes obliged to lease their land to sharecroppers and receive less produce." These households mostly end up in poverty because of lack of male labor which the farming system requires. A study in highland Wollo and Waghamra reflected that female headed households are poorer and more food insecure than male headed households due to gender relations on land access (Devereux et al. 2003).

\section{Experience of woman living in Gozamen woreda (East Gojjam)}

I got married when I was 14 years old. I inherited one pair of oxen from my parents. I gave birth to 4 boys and 5girls. However, once up on a time my boy gets sick. Me and my husband agreed to sell the oxen for medical reasons. Finally, the boy got cured and returned to home. Sooner, we found ourselves a looser, since the oxen used for plowing were sold. Then, we resorted to sharecropping arrangement. We provided the land and labor while the sharecropper provided oxen. The sharecropping left us only onethird of the harvest, a reason to our economic vulnerability. The sharecropping arrangement became a source of conflict. Our vulnerability to food insecurity increased from year to year. Sooner, he divorced me and remarried a woman who has oxen. I neither saved my marriage nor my oxen, but my son. I went to the nearby towns and started to engage in off-farm activities such as selling alcohols. I received nothing from my husband. Now, my case is seen in 
the court, though I do not have any hope of gaining my share from the household.

Women generally lack legal awareness regarding their right to control over household lands. The government authorities at kebele level are also very much hesitant to enforce the legal rights of women. The legal service favored men over women, the strong one over the weak. Besides, lack of awareness, beaurocracies, physical capacity, financial constraints, under-estimation of women by government authorities at kebele and fear of physical violence prohibited women from providing their cases to court.

\section{Experience of widowed woman in Enebise woreda}

I got married when I was 15 years old. My father and mother died 5 years later after my marriage. Sooner, my husband died shortly after our marriage. As soon as he dies his relatives forced me to leave my house. I don't have a child. I still live in my deceased father's house. My father did inherit me nothing, except his old houses. I didn't claim my share because I was afraid of my nephews. I was advised by friends and relatives to claim my share of land. Later, I appealed to the court to justify my inheritance right on my deceased father's land. Five months had already passed since I started the process in the kebele.

Women's land right was also dictated by the amount of money to be paid for local authorities as bribe. The following poem is an indication of how corruption is intensified in the area.

For a man with hundred (Birr)

there is enough fertile land

For a man with fifty Birr

take as per your fate

For a man with ten Birr

let the committee gather

For a man with five Birr

come some other day

For a man with one Birr

just pass by

In general, socio-cultural and institutional factors such as discriminatory cultural practices, low awareness of women on land right, poor law enforcement mechanisms and lower status of women are the most important factors that affects women's land right which in turn led to the vulnerability of women to food insecurity.

\section{Conclusion}

The 1975 land policy was not effectively implemented caused largely due to the society's stereotypes and discrimination against women. Only female headed households were able to get access to land by being registered in PAs, though the land allocated to women was unproductive, swampy and marginal. It also did not consider the gender division of labour in agriculture. This problem was aggravated by lack of productive labor power to cultivate the land. The coming of new government in 1991 brought about a relative conducive environment for women particularly in access to land. Both married and unmarried women despite differences in status were allowed to access land. Besides, the introduction of land certificate has relatively reduced boundary disputes and increased the confidence and the status of women in the society. However, there is significant problem in terms of the degree in which women's control over land. As a result, since customary laws and practices have serious impacts on women's land right, serious attention should be given in order to address constraints related with women's land right. Moreover, women generally lack legal awareness on what extent their right to the rural land is. Therefore, legal awareness campaign should be undertaken towards women and the society. The government needs to provide effective legal aid for women. Besides, the law also has a gap with respect to women in polygamous marriage on how women can get their share from the matrimonial property. This legal gap could be filled by modifying the relevant law.

\section{Acknowledgement}

I would like to thank Bahir Dar University for its funding. I also thank my informants in East Gojjam for the information and their hospitality.

\section{Competing interests}

The author declares no competing interest.

Received: 16 December 2015 Accepted: 19 February 2016

Published online: 11 March 2016

\section{References}

Agarwal B (1994) A field of one's own: gender and land rights in South Asia. Cambridge University Press, Cambridge

Agarwal B (1997) Bargaining and gender relations: within and beyond the household. International Food Policy Research Institute, Washington, D.C. (FCND Discussion Paper No. 27)

Alemayehu R (2001) The role of women in teff production and utilization process. Institute of agricultural research organization, Holeta Agricultural Research Centre

Anteneh B (2008) Gender and agricultural production in Ethiopia: the case of Gozamen Woreda, Amhara Region. Addis Ababa University, MA Thesis

Askale T (2005) Land registration and women's land rights in Amhara region, Ethiopia. Securing Land Rights in Africa. International Institute for Environment and Development, London

Assefa B (2010) The effects of rural land certification in securing land rights: a case of the Amhara region, Ethiopia. Msc Thesis, Netherlands

Creswell J (2005) Educational research: planning, conducting, and evaluating quantitative and qualitative research. Upper Saddle River, Pearson Education, Inc., New Jersey

Crewett W, Bogale, Korf B (2008) Land tenure in Ethiopia: continuity and change, shifting rulers, and the quest for state control. International Food Policy Research Institute, Washington, DC (CAPRi Working Paper, No. 91) 
Daniel W (2012) Land rights in Ethiopia: ownership, equity, and liberty in land use rights. Ethiopia

Davison J (1988) Land and women's agricultural production: the context in agriculture, women and land the African experience. In: Davison J (ed) West view Press. Bould and London

Deere C, León M (2001) Empowering women: land and property rights in latin America. University of Pittsburgh, Pittsburgh

Deininger K, Daniel A, Stein H, Jaap Z (2007) Rural land certification in Ethiopia: process, initial impact, and implications for other African countries. Addis Ababa, Ethiopia.

Dessalegn R (1994) Land tenure and land policy in Ethiopia after the Derg. In Proceeding of the Second workshop of the Land Tenure Project. A.A.U., Institute of Development Research Land Tenure Project, Norway

Dessalegn $R$ (2009) The peasant and the state: studies in agrarian change in Ethiopia (1950's-2000's). Addis Ababa University Press, Addis Ababa

Devereux S, Sharp K, Amare Y (2003) Destitution in wollo, Ethiopia. IDS Research Report 55. IDS, Brighton

FDRE (1995) Federal democratic republic of Ethiopia. Proclamation No. 1/1995. Proclamation of the Constitution of the Federal Democratic Republic of Ethiopia, Addis Ababa

Fong M, Bhushan A (1996) Toolkit on gender analysis in agriculture. Gender Toolkit Series No. 1. World Bank, Washington, DC

Gashaw T (2015) Women's land use right policy and household food security in Ethiopia: review. Int J Afr Asian Stud 12:2015

Gebreselassie S (2006) Land, land policy, and smallholder agriculture in Ethiopia: options and scenarios. Paper prepared for the Future Agriculture Consortium, Institute of Development Studies, Brighton, UK, March 20-22, 2006

Hadera T (2002) Women and land rights in Ethiopia: a comparative study of two communities in Tigray and Oromiya Regional States. The eastern African sub-regional support initiative for the advancement of women (EASSI), Kampala

Hussein A (2014) A woman's right to and control over rural land in Ethiopia: the law and the practice. Int J Gend Women's Stud 2(2):137-165

Kebede B (2008) Land reform, distribution of land and institutions in rural Ethiopia: analysis of inequality with dirty data. J Afr Econ 17(4):550-577

Lemlem A, Ranjitha P, Genvieve R, Dirk H, Susan M (2011) Gender. IPMS, Ethiopia

Meheret A (1994) The Ketto Resettlement: a brief comparative survey of the land tenure system, 1985/86 and 1993. In: Proceedings of the second workshop of the land tenure project. Working Papers on Ethiopian Development, Center for Environment and Development, University of Trondheim, Norway
Mintewab B, Holden S (2010) The role of land certification in reducing gender gaps in productivity in rural Ethiopia. Environment for development: Discussion Paper Series. November 2010

Ojulu L (2015) Gender differences and relations in rural household livelihoods of Gog district, Anywaa zone, Gambella region, south western Ethiopia. Int J Gend Women's Stud 3(1):51-79

Rahmato D (1994) Land tenure and land policy in Ethiopia after the Derg. In: Proceeding of the second workshop of the land tenure project, Norway. AAU, Institute of development research land tenure project

Sachs C (1999) Gender fields: rural women, agriculture and environment. West View Press, London

Sintayehu D (2003) Gender roles in agricultural production among the Sidama of south western Ethiopia. Addis Ababa University Press, Addis Ababa

Stefan D, Daniel A (2007) Land rights power and trees in rural Ethiopia. University of Oxford, Oxford

Teklu T (2005) Land scarcity, tenure change, and public policy in the African case of Ethiopia: Evidence on efficacy and unmet demands for land rights. In: Proceedings of the Third International Conference on Development Studies in Ethiopia, June 18-19. Addis Ababa, Ethiopia

Tenaw S, Zahidul I, Tuulikki P (2009) Effects of land tenure and property rights on agricultural productivity in Ethiopia, Nambia, and Bangladesh. University of Helsinki, Helsinki

Teshome Y (2015) Socio-cultural and Policy related constraints to women's land right: a case study from Gamo highland, SW Ethiopia. Humanit Soc Sci 3(4):149-154

Verma R (2007) Without land you are nobody: critical dimensions of women's access to land and relations in tenure in East Africa Nairobi. IDRC, Ottawa

Wudenesh H. (2003), Gender and Economic development: gender and the agricultural economic sector. In Gender and Economic Policy. Gender Policy Dialogue. Series. Addis Ababa. pp 14-26

Yared A (1995) Land redistribution and its implications for peasant differentiation in Wogda,Northern Shewa. Ethiop J Dev Res 17(1):1-22

Yigremew A (1997) Rural land holding readjustment in West Gojjam, Amhara Region. Ethiopian J Dev Res 19(2):57-89

Zenebe N (2005) Trajectories of women, environmental degradation and scarcity: examining access to and control over resources in Ethiopia. Addis Ababa, Ethiopia

Zenebwork T, Yared A (2000) Women's land rights in Ethiopia. In Berchi: The journal of ethiopian women lawyers association. Vol. 1. No. 1. EWLA, Addis Ababa, Ethiopia, pp 25-51

\section{Submit your manuscript to a SpringerOpen ${ }^{\odot}$ journal and benefit from:}

- Convenient online submission

- Rigorous peer review

- Immediate publication on acceptance

- Open access: articles freely available online

- High visibility within the field

- Retaining the copyright to your article

Submit your next manuscript at springeropen.com 